\title{
Effective e-Government and Citizens Adoption in Egypt
}

\author{
Mohamed M. Abbassy \\ Lecturer, Ministry of High Education, the High \\ Institute for Tourism, Hotels \& Computer, El- \\ Seyouf, Alexandria, Egypt
}

\author{
Saleh Mesbah \\ Associate Professor, Dept. of Information System, \\ College of Computing \& Information Technology, \\ Arab Academy for Science, Technology \& \\ Maritime Transport
}

\begin{abstract}
Electronic Government is essential for most countries worldwide particularly in developing countries, e-Government execution contains technological, governing and social factors, which must be considered and treated carefully in order the end goal to encourage this change. This paper aim to study steps of powerful e-Government and distinguishes the variables that may empower citizen adoption in Egypt. The relevant activities and stakeholders are identified and analyzed to promote the development and effective of eGovernment in Egypt. Factors required to increase citizen adoption are also studied of e-Government in Egypt. Factors required to expand citizen adoption are additionally examined. The results underline key benefits resulting from eGovernment, explain the strategies used in effective and identify citizens' adoption factors in e-Government. The findings also explain the relationships among those effective and identified citizen adoption of governmental e-service development in Egypt.
\end{abstract}

\section{General Terms \\ E-Government}

Keywords

Effective E-Government, E-Government adoption.

\section{INTRODUCTION}

The growing role of Information and Communication Technologies (ICTs) in facilitating and expediting economic, social, cultural and political development is now being understood by most of developing countries. An increasing number of governments are developing national ICT initiatives and strategies. The emerging ICT-for-development approach towards public sector transformation is making new recognition about government and governance.

The term e-Government has become a global phenomenon. Developing countries have been starting E-Government systems and ventures, as a way to promote development [1]. These project can reinforce the performance of government and public administration; furthermore for monetary and social advancement. E-Government projects can contribute to solving administrative issues in developing countries whose public administration is described by wastefulness, limited capacity, and poorly-trained personnel [1]. Electronic or "online" channels can facilitate government communication functions more rapidly, efficiently and cheaply than offline channels [2] [3] [4].

E-Government not only provides advantages, for example, inexpensive and reliable services to native and business additionally offers the possibility to reshape public sector and comment the connections between citizen, business, and the legislature by taking into consideration open-correspondence, interest and public dialogs in planning national regulations [5, 6].
Emergence of the corruption of public administration and their inability to help citizens in the save time and effort and cost, A trend towards reforming the public administration in Egypt has emerged in recent years. It has been spurred primarily by the aspirations of citizens, who are placing new requests on governments. The Egyptian government is endeavoring to revive their public administration and make it more proactive, proficient, straightforward, and particularly more administration arranged and monetary assets for administration conveyance to natives. E-Government can contribute altogether to the procedure of change of the government towards a leaner and more practical government.

E-Government can improve the performance of the government in the following areas [7]:

1- Delivery of services to citizens: Services can be made convenient and easy to access.

2- Delays can be reduced. The rules governing service can be made transparent, and consistent across different branches of the same department, many departments have been able to reduce corruption through eGovernment.

3- Increased Efficiency of Departments/ Government Enterprises: E-Government may lead to lower cost of operations with the resulting higher productivity.

4- Delivery of Services to Business and Industry: Business and industry are concerned with the cost of setting up a business. A significant component of this cost is the administrative permissions and license that must be obtained to establish and operate a business. Electronic delivery can lead to quick turnaround of license applications and lead to an overall reduction in costs.

The main aim of paper is to gain better understanding steps to effective and the factors that affect the citizens' adoption of eGovernment services. These factors will improve the probability of increasing the adoption rate of these services.

\section{E-GOVERNMENT BACKGROUND}

E-Government define from a single perspective is relatively easy, but defining e-Government in a way that suits everyone's view or needs is a significant challenge. MengSeng et al. (2011) noted that although e-Government as a term has become known across the world, there is evidence of insufficient consensus on its meaning, particularly regarding the main features of e-Government [8]. In addition, the use of information technology to enable and increase efficiency key to e-Government, while providing services and information to citizens, employees, businesses and government agencies [9]. A different approach is to define e-Government as using the Internet as a tool for information and communications technology (ICT) to accomplish better government [10].

A wide range of different definitions from researchers have been identified; while everyone has a different view and 
requirements, most of them share the view that e-Government incorporates ICT as one of its major elements. Citizen adoption is a main issue for success of e-Government especially in developing countries. However, growing interest in e-Government raises the question of how governments can increase citizen adoption and use of their online government services [11]. Carter and Belanger (2004) point out that, although numerous studies have analyzed user adoption of electronic commerce, to date, no study has identified the core factors that influence citizen adoption of e-Government initiatives [9] [12]. According to Colesca (2009), many studies focused on the citizen adoption of e-Government services suggested that trust, security and transparency are major issues for e-Government adoption [13] [14] [15] [16]. According to Margetts [17], cited by Yonazi, et al. [18], high adoption of these initiatives increases the chance that eGovernment will facilitate social and economic benefits to citizens. Increasing adoption of electronic administrations by governments, in spite of the level of usage varies from one country to another. A few studies demonstrate that the pace with which electronic administrations are made accessible and adopted is lower than planned in developing country $[19 ; 20$; $21 ; 22]$. Hassan et al noted that Governments tend to be slow in releasing new services and citizens regularly want to lead exchanges with the government through paper frames and physical presence as opposed to utilizing online methods [23]. In next sections will discuss e-Government development between Egypt and gulf country.

\subsection{E-Government Development in Gulf Country and Egypt}

The e-Government development or readiness according to United Nations survey includes online services, human capital and telecommunication infrastructure. According to the UN survey 2014 show that Gulf Cooperation Council (GCC) countries becomes one of the 50 top world leaders in eGovernment development as shown in table 1, Bahrain become 18 and its value index is 0.8089 ,UAE become 32 and its value index is 0.7136 , Saudi Arabia become 36 and its value index is 0.6900 , Qatar become 44 and its value index is 0.6362 , Oman become 48 and its value index is 0.6273 , and Kuwait become 49 and its value index is 0.6268 . In the global ranking Bahrain advanced 18 points from 36th in 2012 to 18 th in 2014. UAE dropped lower ranking position into 4 points in the global ranking from 28th in 2012 to 32th in 2014.
In the global ranking Saudi Arabia advanced 5 points from 41th in 2012 to 36th in 2014. Qatar global ranking advanced 4 points from 48 in 2012 to 44 in 2014, Oman also global ranking advanced 16 point from 64 in 2012 to 48 in 2014 and Kuwait advanced 14 point from 63 in 2012 to 49 in 2014. GCC countries have a goal is to enhance their e-Services, increase the productivity and efficiency of government and improve their ranking in the global e-Government Surveys. $[24,25]$.

Egypt improves its e-Government readiness ranking and its eGovernment development index became 0.5129 in 2014. Its global ranking increase to 80 in 2014 because its improvements begin keeps pace with those of other countries around the globe. Egypt has developed one-stop shop portal; its national website has downloadable forms, and allows the online submission of forms and payment by credit card, all on a secured link. The national website also provides interaction with wireless application protocol. Egypt has also invested in multimedia with video and audio links on its website. Egypt has three mobile operators and has made more initiatives IT skills and computer-based education, but it appeared far behind other Arab countries as shown above in e-Government readiness according to the UN survey $2014[24,25,26]$. The e-Government development or readiness according to United Nations survey includes online services, human capital and telecommunication infrastructure as shown in table 1 .

In figure 1 , the e-Government readiness in Bahrain, UAE, Saudi Arabia, Qatar, Oman and Kuwait show advancement in the e-Government. The government portals of these countries enable many citizen transactional services online as well as using multi-channels to provide the services, for example one of them Saudi Arabia also made progress in its online services. The development in Saudi e-services is the eDashboard portal that utilizes digital verification and serves as single sign-on-portal. The Saudi government offers an open data to provide citizens with documents and reports from government agencies and ministries. Furthermore, SA ranks high in multichannel service delivery because of using various channels. SA is utilized mobile based channels including SMS notification service, mobile applications, payment using mobile phones and separate m-government site. On the other hand, Egypt shows little progress in its e-Government readiness/development regarding other Arabian country special Gulf country. 


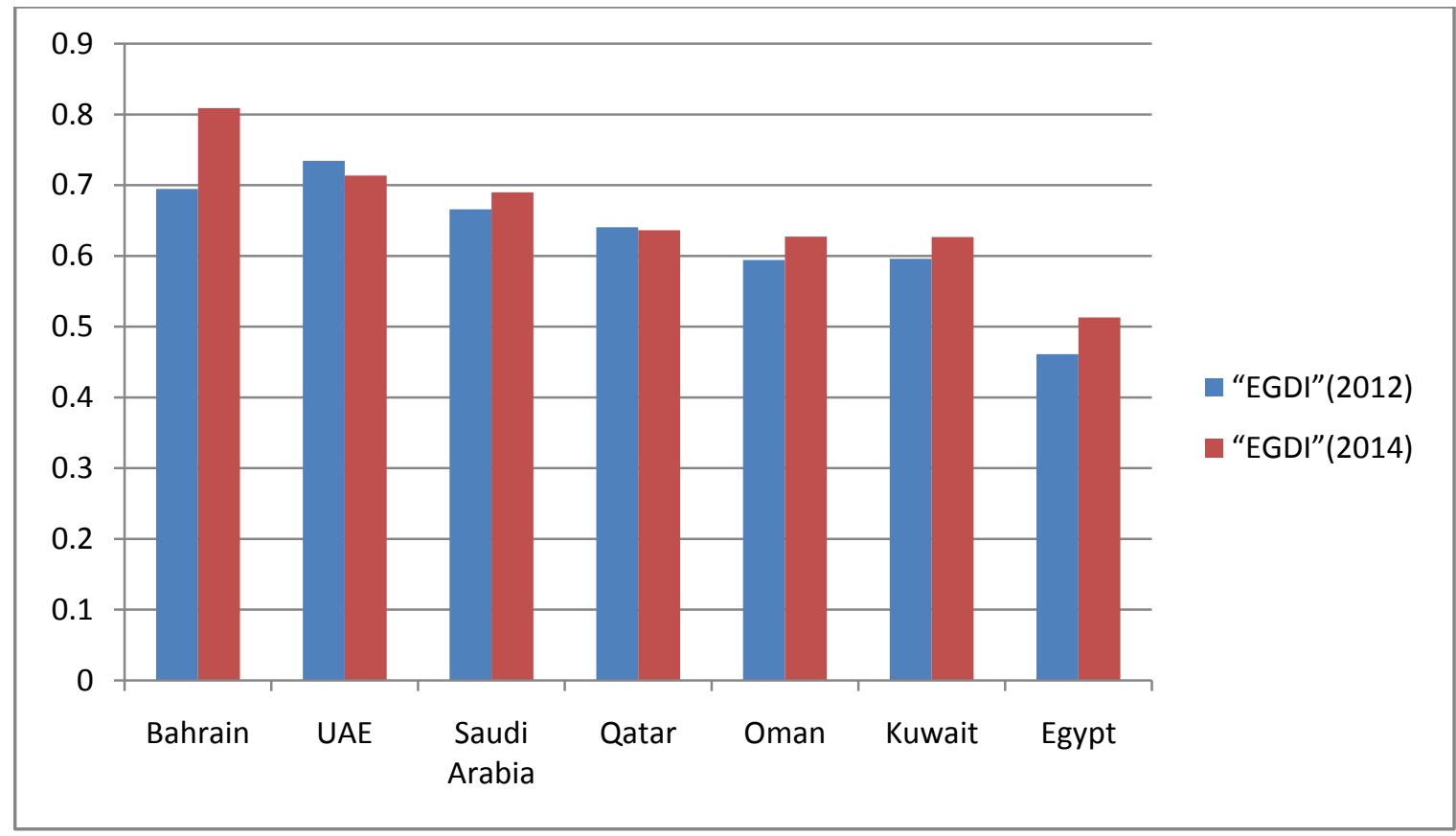

Fig 1: e-Government Development Index (EGDI)

Table1.Egypt and Arabic country E-Government Development

\begin{tabular}{|c|c|c|c|c|c|c|c|}
\hline Country & $\begin{array}{c}\text { OSI } \\
2014\end{array}$ & $\begin{array}{c}\text { TII } \\
2014\end{array}$ & $\begin{array}{l}\text { HCC } \\
2014\end{array}$ & $\begin{array}{c}\text { EGDI } \\
2014\end{array}$ & $\begin{array}{c}\text { EGDI } \\
2012\end{array}$ & $\begin{array}{c}2014 \\
\text { Global } \\
\text { Ranking }\end{array}$ & $\begin{array}{c}2012 \\
\text { Global } \\
\text { Ranking }\end{array}$ \\
\hline Bahrain & 0.9370 & 0.7055 & 0.7840 & 0.8089 & 0.6946 & 18 & 36 \\
\hline UAE & 0.8819 & 0.5932 & 0.6657 & 0.7136 & 0.7344 & 32 & 28 \\
\hline Saudi Arabia & 0.7717 & 0.5523 & 0.7461 & 0.6900 & 0.6658 & 36 & 41 \\
\hline Qatar & 0.6535 & 0.5879 & 0.6671 & 0.6362 & 0.6405 & 44 & 48 \\
\hline Oman & 0.7323 & 0.4873 & 0.6624 & 0.6273 & 0.5944 & 48 & 64 \\
\hline Kuwait & 0.5748 & 0.5862 & 0.7194 & 0.6268 & 0.5960 & 49 & 63 \\
\hline Egypt & 0.5906 & 0.3571 & 0.5912 & 0.5129 & 0.4611 & 80 & 107 \\
\hline
\end{tabular}

\subsection{E-Government Portal in Egypt}

Since 2001, Egyptian government has developed an eGovernment infrastructure to reform administrations for citizens and organizations. The government needed a bilingual Arabic-English accessible to natives, nonnatives, business, and investors. Its purpose is to empower all partners to browse the government's recent announcements, search for information related to particular government services, and access online services to submit request and transactions electronically, all at a solitary 'one stop shop' [27]. In 2004, The Egyptian Ministry of State for Administrative Development (MSAD) initiated the development plan of EGovernment Programs. This plan covers for approximately $54 \%$ of government services to be available by telephone and Internet services by the close of year 2007. Both Ministry of State for Administrative Development (MSAD) and Ministry of Communications and Information Technology (MCIT), is responsible for leading the country's E-Government program to have most services for citizens and businesses online. The commercial partners assisting in the implementation of these efforts include Oracle and Microsoft [28, 29].

The e-Government portal in Figure 2 offers content in both Arabic and English to provide services to people, organizations, and nonnatives. The website provides epayment facility and the accessibility to download the essential document for achieving government services. The services provided by the e-Government incorporate advanced resources store, land transportation administrations, activity lawyer and vehicle licenses administrations, and in addition online services for business, for example, qualified Industrial zone services and environmental services. Moreover the e- 
Government offers online services to nonnatives, for example, Egypt aircraft ticketing services and cultural services. [28].

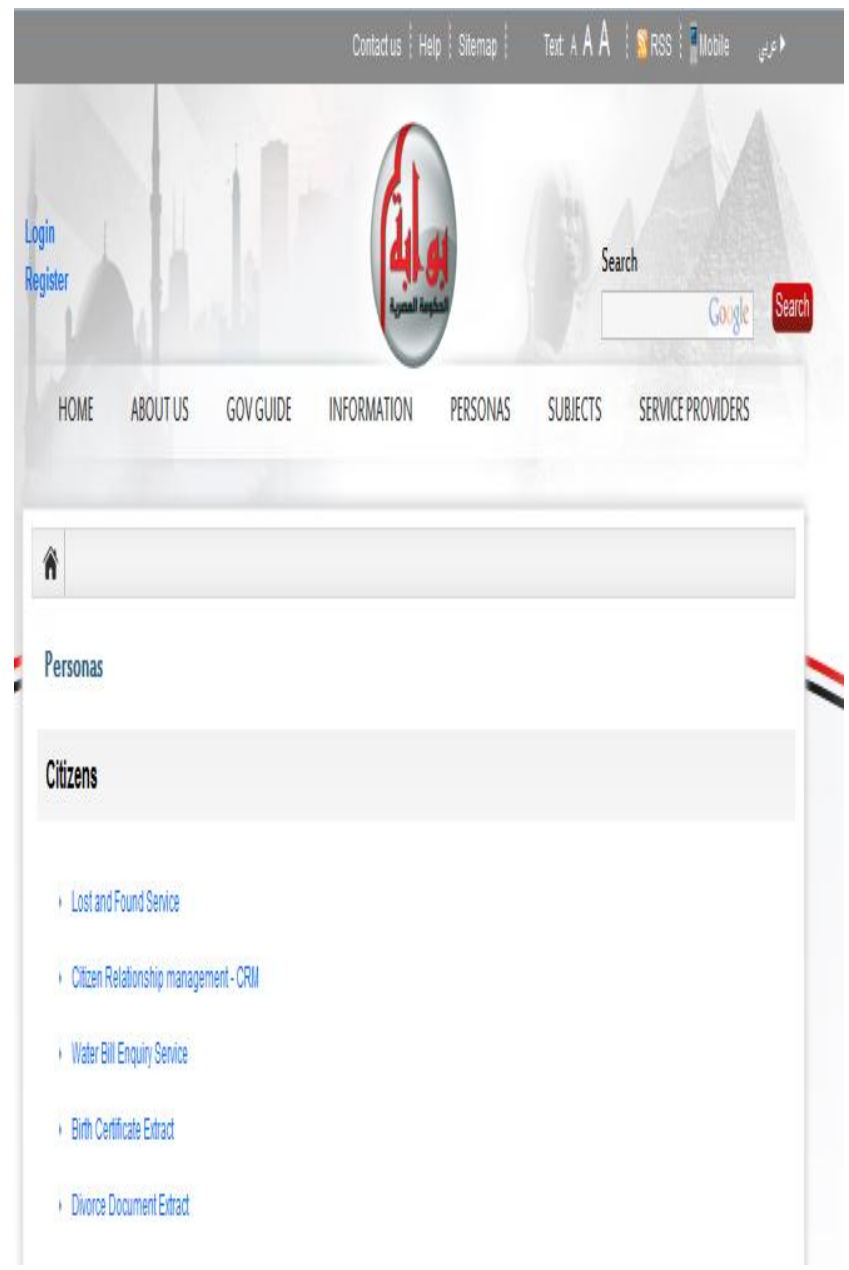

Fig 2: E-Government Portal in the Egypt

\subsection{The Information and Communication Technology in Egypt:}

Information and communication technology (ICT) infrastructure plays an important role in a success of eGovernment in any country; therefore, now will discuss the ICT in Egypt:

A more stable domestic political and economic environment, combined with a supportive policy environment, has helped the Egyptian IT market to return to a robust growth trajectory after disruption due to political crisis in recent years. Computer Hardware Sales: EGP7.06bn in 2014 to EGP7.87bn in 2015 , up $11.5 \%$ in local currency terms. Depreciation of the Egyptian pound against the US dollar will be a drag on market growth in 2015, but strong demand for low-cost tablets will ensure growth continues. Software Sales, EGP2.51bn in 2014 to EGP3.02bn in 2015, up 20.4\% in local currency terms. IT Services Sales, EGP3.50bn in 2014 to EGP4.21bn in 2015, up
$20.3 \%$ in local currency terms. IT services growth will be driven by the expansion of the local outsourcing and software development industry, further supported by rising public and private sector demand for cloud-based infrastructure and platform services. The internet usage has grown from 20.136 million in 2009 to 32.62 million in 2012 to be 40.311 .562 in 2014 [30].

Table 2. ICT in EGYPT

\begin{tabular}{|l|l|}
\hline Computer Hardware Sales & EGP7.87bn \\
\hline Software Sales & EGP3.02bn \\
\hline IT Services Sales & EGP4.21 \\
\hline Internet usage & 40.311 .562 \\
\hline
\end{tabular}

\section{RESEARCH MODEL}

From previous studies show Egypt e-Government problem and challenge related to security, privacy and trust of using eservice, providing IT skills and computer or internet programs will increase the citizen's awareness of using online services, transforming the traditional government processes to fully online services as well as improving the efficiency of the public sector.

\subsection{Improve e-Government implementation in Egypt}

To improve e-Government responsiveness, service quality and accessibility. This paper shows the main stakeholders and activities in e-Government to effective

The lawmakers are responsible for introducing, maintaining and abolishing legislation on e-Government.

The government employees are responsible for announce about e-Government systems.

The ICT industry is responsible for developing the e government and their service. This includes user requirements, deriving system specification, performing analysis and design and finally implements the system.

Finally, the users of e-Government mainly include government employees who will operate the e-Government and end-users (citizens, businesses and other public servants) who will use e-Government.

Can be concluding steps improve e-Government implementation as shown in figure 3 


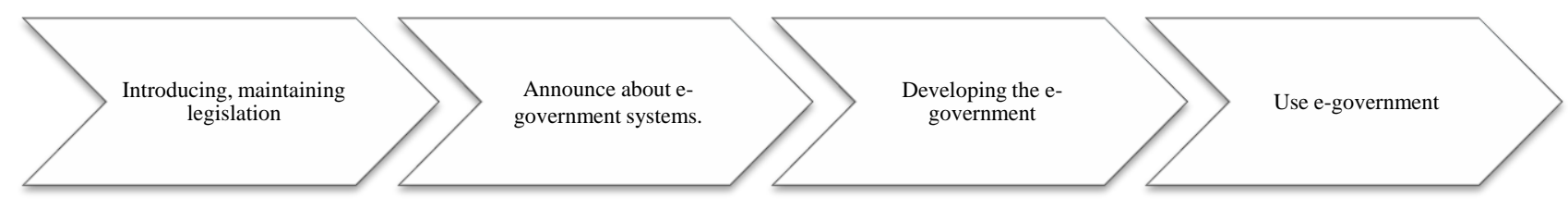

Fig 3: Steps to effective e-Government implementation

\subsection{Factors for e-Government Adoption in Egypt}

This paper suggests e-Government factors to develop the implementation and increase citizen adaptation in Egypt enclosed by governing, social and information technology factors as illustrated the following:

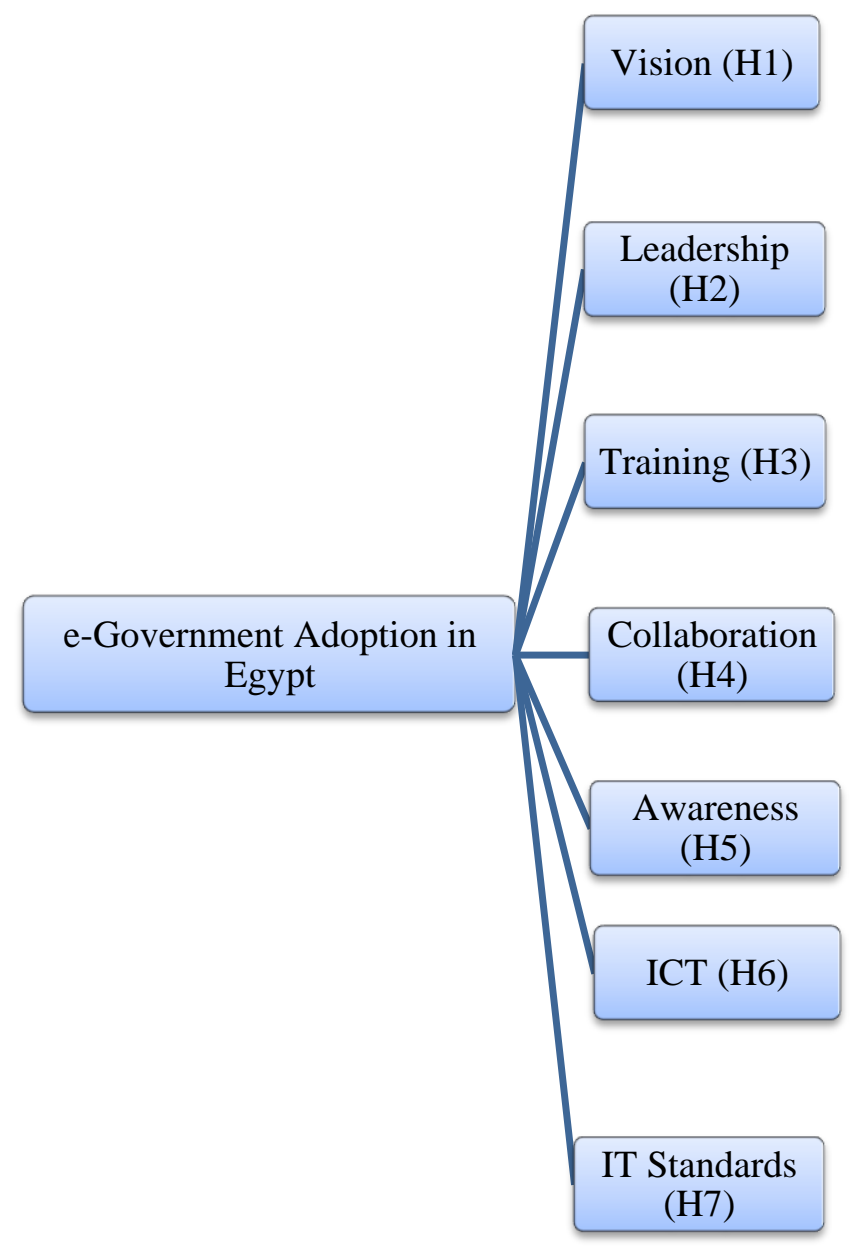

First: Vision should be from start from planning process, creating a picture of the future, realistically and clarify to generate commitment to performance.

Second: Leadership: is one of the important factors for the EGovernment success. e-Government adoption is a strong leadership with vision.

Third: Training: is important factor in e-Government because if people can't use the technologies, they can't take responsibility.

Forth: Collaboration: e-Government requires collective efforts from many government public sectors.

Five: Awareness: includes using the mass media to introduce the concept of E-Government for people in the public sectors, and show the benefits of E-Government and important of implementing E-Government. The time and cost of giving administrations to enabling the workers, diminishing organization, and expanding productivity are these advantages.

Six: Information and Communication Technologies: is important key in implement and develop e-Government is communications infrastructure, not only a sufficient distribution of computer technology or social, but also the general applying of telecommunication services is an essential for the attainment of a certain standard of E-Government system.

Seven: IT Standards: which mean specifications for hardware and software, its Play important role in helping people to manage and use technology, Single integrated gateway model for adoption of E-Government is expected to provide access to its information and services that requires the government public sectors must share information, knowledge, participate positively, and collaborate to provide E-Government services.

In the present paper, the developed model for e-Government adoption in Egypt is based on current e-Government problems in Egypt, also how to encourage citizens and government employee to adopt e-Government. This model consists of the seven factors, enclosed by governmental, social and Information Technology factors as shown in Figure 4. 


\subsection{Effective Development of e- Government in Egypt}

Egypt government must put their main aim is upgrading the productivity and effectiveness of public sector; providing better and efficient services to citizens and business in a convenient way and improving the trustworthiness and promptly access of government information. To accomplish this goal through:

1- Reengineering processes of the government activities according to the requirement of the e-Government.

2- Reviewing technical and administrative experiences of some countries in order to benefit from their experience in the field of implementing the e-Government.

3- Unifying the Home page working policies on the internet and the general standards which will be followed at government authorities to create their pages for easy linking in the future.

4- Telecommunications companies must play an important role for enhancing the telecommunication infrastructure through providing converged telecommunication services mobile phone and fibre-optic networks to provide more reliable internet connections.

5- Egypt E-Government portal should be separate epayment system linked to all channels of the Egypt banks to handle all online transactions.

The citizens' awareness about the significance of online service provided needs to be increased addition to providing more transactional services for individuals, organizations and business. The citizens in Egypt still need learn, help to be familiar with how to use the e-services. The citizens need also to be awareness of trust, privacy and security as important issues for e-Government.

\section{CONCLUSION}

This paper, investigates the role of effective e-Government and the citizen adoption of e-Government services in Egypt. It is motivated by transforming the traditional government processes to fully online services as well as improving the efficiency of the public sector. E-Government services cannot improve public service delivery if they are not used by the public. Identifying such elements will enhance the probability of deepening so as to expand the reception rate of these administrations the information about the variables which encourage, or impede, the adoption process. This paper results suggest that Egypt should be increasing use of communication technologies, internet, social networking and the fast-growing educated population to do best practice in e-Government like United Arab Emirates. Process reengineering and unifying home page working policies are the key success for eGovernment. On the other hand, Egypt eGovernment vision ought to be improving the efficiency and productivity of the public sector and efficient services to citizens and business in a convenient way and upgrading the uprightness and promptly access of government data.

\section{REFERENCES}

[1] Schuppan, T. (2009), "E-Government in Developing Countries: Experiences from Sub-Saharan Africa", Government Information Quarterly, vol. 26, no. 1, pp. 118-127.

[2] Heeks, R. (2001), Understanding E-Governance for Development, Paper No. 11, I-Government Working
Paper Series, Development Informatics Group, Institute for Development Policy and Management, University of Manchester, Manchester, UK.

[3] Lau, T. Y., Aboulhoson, M., Lin, C. and Atkin, D. J. (2008), "Adoption of E-Government in Three Latin American Countries: Argentina, Brazil and Mexico", Telecommunications Policy, vol. 32, no. 2, pp. 88-100.

[4] Al-Mamari, Q., Corbitt, B. and Gekara, V.O.(2013), "EGovernment adoption in Oman: motivating factors from a government perspective", Transforming Government, People, Process and Policy, Vol. 7 No. 2, pp. 199-224.

[5] Tan W. and Subramanian R. (2005), "E-Government: Implementation policies and best practices from Singapore", Electronic Government strategies and implementation, pp. 305324.

[6] Ke, W. and Wei K. (2004). "Successful E-Government in Singapore", Communication of the ACM, 47(6), pp. 95 99.

[7] Bhatmagar S., (2002) "E-Government: Lessons from Implementation in Developing Countries", Published in Regional Development Dialogue, Vol. 24, UNCRD, Autumn Issue.

[8] W. Meng Seng, N. Hideki, and P. George, "The Use of Importance-Performance Analysis (IPA) in Evaluating Japan's E-Government Services," Journal of Theoretical and Applied Electronic Commerce Research, vol. 6, pp. 17-30, Aug. 2011.

[9] L. Carter and F. Belanger, "Citizen Adoption of electronic government initiatives," in System Sciences 2004. , Proceedings of the 37th Annual Hawaii International Conference, 2004, p. 10

[10] I. Alghamdi, R. Goodwin, and G. Rampersad, "EGovernment Readiness Assessment for Government Organizations in Developing Countries," Computer and Information Science, vol. 4, pp. 3-17, May 2011.

[11] M. Warkentin, D. Gefen, P. A. Pavlou, and G. M. Rose, "Encouraging Citizen Adoption of e-Government by Building Trust," Electronic Markets, vol. 12, pp. 157162,2002 .

[12] D. Gefen, E. Karahanna, and D. W. Straub, "Trust and TAM in Online Shopping: An Integrated Model," MIS Quarterly, vol. 27, pp. 51-90,2003.

[13] S. E. Colesca, "Increasing E-Trust: A Solution To Minimize Risk in e-Government Adoption," Journal of Applied Quantitative Methods, vol. 4, pp. 31-44, 2009.

[14] S. C. Srivastava and T. S. H. Teo, "Citizen Trust Development for E-Government Adoption: Case of Singapore," in "Proocedings of Pacific Asia Conference on Information Systems, 2005, pp. 721- 724

[15] S. Colesca, "The main factors of on-line trust," Economia. Seria Management, vol. 1O, pp. 27-37, 2007.

[16] S. Marche and J. D. McNiven, "E-Government and EGovernance: The Future Isn't What It Used To Be," Canadian Journal of Administrative Sciences / Revue Canadienne des Sciences de l'Administration, vol. 20, pp. 74-86, 2003.

[17] H. Margetts, "E-Government in Britain-A Decade On," Parliamentary Affairs, vol. 59, pp. 250-265, 2006. 
[18] J. Yonazi, H. Sol, and A. Boonstra, "Exploring Issues Underlying Citizen Adoption of e-Government Initiatives in Developing Countries: The Case of Tanzania." Electronic Journal of e-Government, vol. 8, pp. 176-188, Dec 2010.

[19] Vassilakis, C., Lepouras, G., Fraser, J., Haston, S. and Georgiadis, P. (2005), "Barriers to Electronic Service Development", E-Service Journal, vol. 4, no. 1, pp. 4163.

[20] Colesca, S.E. and Dobrica, L. (2008), "Adoption and use of e-Government services: the case of Romania", Journal of Applied Research and Technology, Vol. 6 No. 3, pp. 204-17.

[21] Criado, J.I. (2009), "Europeanization of e-Government policy: institutional mechanisms and implications for public sector innovation", Information Polity: The International Journal of Government and Democracy in the Information Age, Vol. 14 No. 4, pp. 299-314.

[22] Paroski, M., Konjovic, Z. and Surla, D. (2013), "Implementation of e-Government at the local level in underdeveloped countries: The case study of AP Vojvodina", the lelctronic Library, Vol. 31 No.1, pp.99118 .

[23] Hassan, H., Shehab, E. and Peppard, J. (2011), "Recent Advances in E-Service in the Public Sector: State of-theArt and Future Trends", Business Process Management Journal, vol. 17, no.3.

[24] UN Report (2014), "United Nations e-Government Survey 2014: E-Government for the future we want", United Nations Publication, New York,
http://unpan3.un.org/egovkb/Portals/egovkb/Documents/ un/2014-Survey/EGov_Complete_Survey-2014.pdf"

[25] UN Report (2012), "United Nations e-Government Survey 2012: E-Government for people", United Nations Publication,NewYork,"http://unpan3.un.org/egovkb/Pors /egovkb/Documents/un/2012-Survey/unpan048065.pdf “

[26] Gebba T. and Zakaria M., (2012). "E-Government in Egypt: An Analysis of Practices and Challenges", International Journal of Technology and Management, 1(1), pp. 11-25.

[27] Microsoft Case Study, (2007), "Egypt Establishes EGovernment Infrastructure", Microsoft Corporation, August.http://www.microsoft.com/casestudies/Microsoft -Enterprise-Strategy-Consulting-Services/Ministry-ofState-for-Administrative-Development-Egypt/EgyptEstablishes-E-Government -Infrastructure/4000000619

[28] UN- ESCWA (2011), Economic and Social Commission for Western Asia (ESCWA), "National Profile for the Information Society in Egypt", United Nations-New York. http://www.escwa.un.org/wsis/reports/docs/Egypt11-E.pdf

[29] Microsoft Customer Solution Case Study, (2004), "Egypt saves 900,000 working hours a year with E-Government portal for online services to citizens", Microsoft Windows Server2003, Microsoft Corporation, October.

[30] Business Monitor International-Egypt (2015), "Egypt Information Technology Report", Business Monitor International,secondquarter,"http://store.bmiresearch.co $\mathrm{m} /$ catalog/product/view/id/3788 “ 